NBER WORKING PAPER SERIES

\title{
INTERNAL FINANCE AND FIRM INVESTMENT
}

\author{
R. Glenn Hubbard \\ Anil K. Kashyap \\ Toni M. Whited
}

Working Paper No. 4392

\section{NATIONAL BUREAU OF ECONOMIC RESEARCH 1050 Massachusetts Avenue \\ Cambridge, MA 02138 \\ June 1993}

We are grateful to Ben Bernanke, Mark Gertler, Kevin Hassett, Frederick Mishkin, and two anonymous referees for helpful comments and suggestions and to John Barkoulas for excellent research assistance. Kashyap thanks the National Science Foundation, the University of Chicago IBM Faculty Research Fund and the Federal Reserve Bank of Chicago for support. Hubbard thanks the Faculty Research Fund of Columbia University Graduate School of Business for support. This paper is part of NBER's research program in Corporate Finance. Any opinions expressed are those of the authors and not those of the National Bureau of Economic Research. 
NBER Working Paper \#4392

June 1993

\title{
INTERNAL FINANCE AND FIRM INVESTMENT
}

\begin{abstract}
We examine the neoclassical investment model using a panel of U.S. manufacturing firms. The standard model with no financing constraints cannot be rejected for firms with high (pre-sample) dividend payouts. However, it is decisively rejected for firms with low (pre-sample) payouts (firms we expect to face financing constraints). Here, investment is sensitive to both firm cash flow and macroeconomic credit conditions, holding constant investment opportunities. Sample splits based on firm size or maturity do not produce such distinctions. The latter comparison identifies firms where "free-cash-flow" problems might be expected to produce correlations between investment and cash flow.
\end{abstract}

R. Glenn Hubbard

Graduate School of Business

Columbia University

Uris Hall 609

New York, NY 10027

and NBER

Toni M. Whited

Department of Finance

The Wharton School

University of Pennsylvania

Philadelphia, PA 19104-6367
Anil K. Kashyap

Graduate School of Business

University of Chicago

1101 East 58th Street

Chicago, IL 60637

and NBER 


\section{Introduction}

Recent research on determinants of firm-level fixed investment has stressed the importance of proxies for firms' internal finance as an explanatory variable, holding constant measures of firm opportunities or the cost of capital. ${ }^{1}$ Most such studies have been based on departures from neoclassical investment models with perfect capital markets in the direction of models based on asymmetric information in financial markets. These departures build on insights from theoretical models of financial contracting under asymmetric information (using adverse selection and/or moral hazard examples), in which movements in internal funds predict movements in investment spending, holding constant investment opportunities. ${ }^{2}$

Many studies using different specifications of the neoclassical investment model and different data sets have convincingly rejected simple models based on the null hypothesis of perfect capital markets. ${ }^{3}$ Moreover, departures from the perfect-capital-markets benchmark model indicate a role for internal funds. In particular, empirical studies using firm-level panel data show greater failure of the perfect-capital-markets neoclassical investment model for firms selected to be a priori more likely to face capital-market frictions.

Given this background, our paper has two purposes. First, we use an estimation strategy based on the Euler equation representation of firms' investment decisions. This strategy reflects reservations 
with standard investment models based on the $q$ theory with adjustment costs. In particular, there are well-known problems in measuring marginal $q$, as well as concerns that observed stock market valuations may not accord with the predictions of the efficient markets hypothesis (owing either to irrational behavior or to the very problems of asymmetric information stressed in alternative models).

Our second purpose is to explore the reasons why the standard Euler equation for fixed investment may not fit well for all firms. In this investigation we analyze data from Standard and Poor's COMPUSTAT and separate the sample into several subsamples. Our starting point is a comparison of the investment of one set of firms for which the neoclassical model is assumed to hold to the investment of another set for which "financing constraints" are assumed to be important. These samples are constructed based on pre-sample dividend payout ratios, with "high-payout" firms in the first sample and "low-payout" firms in the second. The rationale for this delineation, a feature of many studies in the empirical literature, is presented in section $2 .^{4}$ The standard model, in which there are no capital market frictions, cannot be rejected for a sample of firms with high pre-sample dividend payout ratios. On the other hand, the orthogonality conditions implied by the standard model are decisively rejected for firms with low presample payout ratios. In trying to further understand these findings, we examine several alternative explanations. 
Our first alternative is that the low-payout firms face a particular type of financing constraint..$^{5}$ For tractability we assume that these financing constraints are related to firms' cash flow, so that the effective discount rate for one of these firms depends on its cash flow. One novel aspect of our estimation is that we use firm tax payments as an instrumental variable. To the extent that the marginal product of capital is mismeasured, variables such as "cash flow" are correlated with this measurement error, since they proxy for managers' perceived profitability. Therefore, their addition to the model may improve its fit. Using tax payments as an instrument minimizes the significance of this measurement-error problem, since tax payments are very imperfectly correlated with firm profitability owing to such factors as tax-loss carryforwards and carrybacks (see, for example, Auerbach and Poterba, 1987). For firms for which the standard model fails, cash flow affects investment in a way suggested by our alternative model; they do not matter for the other firms.

A second alternative is to allow the effects of borrowing constraints in our extended model to vary not only with firms' individual fortunes but also with macroeconomic conditions. Here we draw on the recent literature that emphasizes the spread between risky and default-free interest rates as a measure of the tightness of overall borrowing conditions. ${ }^{6}$ Specifically, we parameterize borrowing constraints so that both a firm's own cash flow and these spreads affect the extent 
to which the constraints bind. Taking account of macroeconomic conditions significantly improves the performance of the model.

Finally, we provide some evidence on the nature of the capitalmarket imperfections that might be responsible for our findings. The "free cash flow" models of Jensen (1986) and others have suggested that observed links between investment spending and internal finance could reflect managers' decisions to ignore signals from market valuation in favor of overinvestment in growth. Hence, a finding of a positive correlation between investment and cash flow need not be construed as evidence in favor of financing constraints. In fact there is very little empirical work that can be used to discriminate between the Jensen hypothesis and the financing constraints hypothesis, even though both hypotheses start from a presumption that information and incentive problems are important. To distinguish between the two alternatives, we contrast the behavior of a set of mature firms in our sample with the remaining firms. Although the mature firms are selected to fit Jensen's description, we find that their business fixed investment is well described by a standard Euler equation. Thus, while the Jensenstyle agency model may well be important in explaining other uses of firms' resources, it does not appear to be important for business fixed investment. $^{7}$

The paper is organized as follows. In section 2 , we derive an investment model based on the Euler equation corresponding to firms' 
intertemporal optimization problem for capital accumulation. In the presence of financial constraints, the Euler equation contains testable implications for alternative models. Section 3 outlines a set of tests to exploit cross-sectional predictions of this framework for differences in the appropriate specification of investment models for "constrained" and "unconstrained" firms. The data and our empirical tests are reported in sections 4 and 5 . Section 6 concludes.

\section{Modeling the Investment Decision}

Analyzing investment demand begins with an expression for the value of the firm, which in turn sterns from the arbitrage condition governing the valuation of shares. ${ }^{8}$ The after-tax return to the owners of the firm at time $t$ reflects capital appreciation and current dividends. In equilibrium, if the owners are to be content holding their shares, this return must equal their required return, $R_{i t}$.

$$
\frac{(1-c)\left(E_{t}\left(V_{i, t+1}-S_{i, t+1}\right)-V_{i t}\right)+(1-\theta) E_{t} d_{i, t+1}}{V_{i t}}=R_{i t},
$$

where, $V_{i t}$ is the value of firm $i$ at time $t ; S_{i, t+1}$ denotes the value of new shares issued at time $t+1 ; c$ is an accrual-equivalent capital gains tax rate; and $E_{t}$ is the expectation operator conditional on information known at time $t$. The after-tax capital gain of the current shareholders thus consists of the change in the market value of the firm less the component of this change due to new share issues. The dividends of 
the firm at time $t+1$ are $d_{i, t+1}$, and $\theta$ is the tax rate on dividends.

In the absence of any bubbles, solving (1) forward yields the following expression for the firm's market value at time zero, where $\beta_{i j}$ is the firm's one-period discount factor.

$$
V_{i 0}=E_{0} \sum_{t=0}^{\infty}\left[\prod_{j=0}^{t-1} \beta_{i j}\right]\left(\left(\frac{1-\theta}{1-c}\right) d_{i t}-S_{i t}\right)
$$

The firm maximizes equation (2) subject to five constraints. The first is the capital stock accounting identity:

$$
K_{i t}=I_{i t}+(1-\delta) K_{i, t-1}
$$

where $K_{i t}$ is the capital stock of firm $i$ at the end of time $t, I_{i t}$ is its investment at time $t$ and $\delta$ is the constant rate of economic depreciation. The second constraint defines firm dividends. Cash inflows include sales, new share issues, and net borrowing, while cash outflows consist of dividends, factor and interest payments, and investment expenditures.

$$
\begin{aligned}
d_{i t} & =(1-\tau)\left(F\left(K_{i, t-1}, N_{i t}\right)-w_{t} N_{i t}-\psi\left(I_{i t}, K_{i, t-1}\right)-i_{t-1} B_{i, t-1}\right) \\
& +S_{i t}+B_{i t}-\left(1-\pi_{t}^{e}\right) B_{i, t-1}-p_{i t} I_{i t}
\end{aligned}
$$

where:

$N_{i t}=$ a vector of variable factors of production for firm $i$ at time $t$ $w_{t}=\mathrm{a}$ vector of real factor prices at time $t$

$B_{i t}=$ the real value of net debt outstanding for firm $i$ at time $t$ $i_{t}=$ the nominal interest rate paid on corporate bonds at time $t$ 
$\pi_{t}^{e}=$ the expected inflation rate at time $t$

$p_{i t}=$ the price of capital goods at time $t$ relative to the price of output at time $t$ (incorporating tax considerations)

$\tau=$ the corporate income tax rate

$F\left(K_{i, t-1}, N_{i t}\right)=$ the firm's real revenue function $\left(F_{K}>0, F_{K K}<\right.$ $0)$

$\psi\left(I_{i t}, K_{i, t-1}\right)=$ the real cost of adjusting the capital stock $\left(\psi_{I}>\right.$ $0, \psi_{I I}>0, \psi_{K}<0$, $\left.\psi_{I K}<0\right)$

The third constraint restricts dividends to be non-negative.

$$
d_{i t} \geq 0
$$

The fourth constraint limits share repurchases. This restriction is necessary since the differential between the taxes on dividends and capital gains allows the firm to increase its value by cutting dividends and using share repurchases to distribute cash to its stockholders.

$$
S_{i t} \geq \underline{S}
$$

The fifth constraint is a transversality condition which prevents the firm from borrowing an infinite amount to pay out as dividends:

$$
\lim _{T \rightarrow \infty}\left[\prod_{j=t}^{T-1} \beta_{i j}\right] B_{i T}=0, \forall t .
$$

Let $\lambda_{i t}$ be the series of Lagrange multipliers associated with the constraint (5), and let $m$ represent the ratio $(1-\theta) /(1-c)$. Substituting 
(4) into (2) for $d_{i t}$, and using (3) to eliminate $I_{i t}$ from the problem, the first order conditions for the capital stock $\left(K_{i t}\right)$ and the stock of net external debt $\left(B_{i t}\right)$ can be calculated as:

$$
\begin{gathered}
E_{t} \beta_{i t}\left[( \frac { m + \lambda _ { i , t + 1 } } { m + \lambda _ { i t } } ) \left(F_{K}\left(K_{i t}, N_{i, t+1}\right)-\psi_{K}\left(I_{i, t+1}, K_{i t}\right)\right.\right. \\
\left.\left.+(1-\delta)\left(\psi_{I}\left(I_{i, t+1}, K_{i t}\right)+\frac{p_{i, t+1}}{(1-\tau)}\right)\right)\right]=\psi_{I}\left(I_{i t}, K_{i, t-1}\right)+\frac{p_{i t}}{(1-\tau)} \\
\left(m+\lambda_{i t}\right)-\beta_{i t}\left(1+(1-\tau) i_{t}-\pi_{t}^{e}\right) E_{t}\left(m+\lambda_{i, t+1}\right)=0
\end{gathered}
$$

To obtain an equation for investment, it is necessary to parameterize the adjustment cost function, $\psi\left(I_{i t}, K_{i, t-1}\right)$. The tradition in the $q$ literature since Summers (1981) and Hayashi (1982) has been to specify adjustment costs that are linearly homogeneous in investment and capital, so that marginal and average $q$ will be equal (see Hayashi, 1982). A convenient parameterization that adheres to these constraints is:

$$
\psi\left(I_{i t}, K_{i, t-1}\right)=\frac{\alpha}{2}\left(\frac{I_{i t}}{K_{i, t-1}}-v\right) I_{i t} .
$$

where the bliss point in the adjustment function is given by $v .^{9}$ By differentiating (10) with respect to $I_{i t}$ and $K_{i t}$, and substituting these results into $(8)$, one obtains: 


$$
\begin{gathered}
E_{t} \beta_{i t}\left[( \frac { m + \lambda _ { i , t + 1 } } { m + \lambda _ { i t } } ) \left(F_{K}\left(K_{i t}, N_{i, t+1}\right)+\frac{\alpha}{2}\left(\frac{I_{i, t+1}}{K_{i t}}\right)^{2}\right.\right. \\
\left.\left.+(1-\delta)\left(\alpha\left(\frac{I_{i, t+1}}{K_{i t}}\right)+\frac{p_{i, t+1}}{(1-\tau)}-v\right)\right)\right]=\alpha\left(\frac{I_{i t}}{K_{i, t-1}}\right)+\frac{p_{i t}}{(1-\tau)}-v
\end{gathered}
$$

We assume that expectations are rational and allow for an expectational error, $e_{i, t+1}$, where $E_{t}\left(e_{i, t+1}\right)=0$ and $E_{t}\left(e_{i, t+1}^{2}\right)=\sigma_{e}^{2}$. The error is uncorrelated with any information known at time $t$. This assumption and equation (9) allow us to write equation (11) as:

$$
\begin{gathered}
\left(\frac{1}{1+(1-\tau) i_{t}-\pi_{t}^{e}}\right)\left[F_{K}\left(K_{i t}, N_{i, t+1}\right)+\frac{\alpha}{2}\left(\frac{I_{i, t+1}}{K_{i t}}\right)^{2}\right. \\
\left.+\alpha(1-\delta) \frac{I_{i, t+1}}{K_{i t}}+(1-\delta)\left(\frac{p_{i, t+1}}{(1-\tau)}-v\right)\right] \\
-\alpha \frac{I_{i t}}{K_{i, t-1}}-\frac{p_{i t}}{(1-\tau)}+v=e_{i, t+1}
\end{gathered}
$$

To move from equation (11) to (12), we have also made the strong assumption that the conditional covariance between $\left(m+\lambda_{i, t+1}\right) /$ $\left(m+\lambda_{i t}\right)$ and other $t+1$ dated variables is constant. Under the null hypothesis of no capital-market frictions, this is a natural assumption since this term should equal unity. Thus, in principle, one reason why the restrictions implied by equation (12) might be rejected is the failure of this assumption. In practice, this assumption will fail in the presence of financing constraints, since one of the manifestations of financing problems will be a binding constraint on dividend payout. Since one of our goals is to develop a parametric alternative model 
that allows for borrowing constraints, we are forced to take a stand on how such constraints might operate. By making the strong simplifying assumption that this conditional covariance is constant, we therefore are constructing an alternative model that emphasizes the relaxation of borrowing constraints rather than the relaxation of a dividend payout constraint. Because the two constraints are so closely linked, this distinction is arbitrary, but we would be unable to develop an alternative model without addressing this issue.

In our extended model we incorporate financial factors by adding a constraint on the use of debt finance by firms. In particular, we assume that the outstanding debt, $B_{i t}$, must be less than a debt ceiling $B_{i t}^{*}{ }^{10}$ The ceiling, while possibly unobservable to the econometrician, depends on measures of firm financial health. That is, movements in firms' financial health will affect their ability to finance investment, holding constant actual investment opportunities. If we let $\omega_{i t}$ represent the series of Lagrange multipliers associated with the constraint that $B_{i t} \leq B_{i t}^{*}$, we can rewrite the first-order condition in (9) as:

$$
\left(m+\lambda_{i t}\right)-\beta_{i t}\left(1+(1-\tau) i_{t}-\pi_{t}^{e}\right) E_{t}\left(m+\lambda_{i, t+1}\right)-\omega_{i t}=0
$$

It is convenient to normalize $\omega_{i t}$ relative to $\left(m+\lambda_{i t}\right)$ and denote the resulting ratio by $\tilde{\omega}_{i t}$. In this case $\beta_{i t}$ equals:

$$
\beta_{i t}=\frac{1-\tilde{\omega}_{i t}}{\left(1+(1-\tau) i_{t}-\pi_{t}^{e}\right)} E_{t} \frac{\left(m+\lambda_{i, t+1}\right)}{\left(m+\lambda_{i t}\right)}
$$


Accordingly, (12) would then be amended to:

$$
\begin{gathered}
\left(\frac{1-\tilde{\omega}_{i t}}{1+(1-\tau) i_{t}-\pi_{t}^{e}}\right)\left[F_{K}\left(K_{i t}, N_{i, t+1}\right)+\frac{\alpha}{2}\left(\frac{I_{i, t+1}}{K_{i t}}\right)^{2}\right. \\
\left.+\alpha(1-\delta) \frac{I_{i, t+1}}{K_{i t}}+(1-\delta)\left(\frac{p_{i, t+1}}{(1-\tau)}-v\right)\right] \\
-\alpha \frac{I_{i t}}{K_{i, t-1}}-\frac{p_{i t}}{(1-\tau)}+v=e_{i, t+1}
\end{gathered}
$$

Under the hypothesis of perfect capital markets, both the constraints on outside debt and equity finance are redundant, so that $\omega_{i t}=0$. The multiplier $\lambda_{i t}$ represents the value of a marginal dollar of cash flow to the firm. $\lambda_{i t}$ is zero in period $t$ when firm $i$ is paying dividends. Under the assumptions here, a firm expecting to pay dividends in the current and future periods $\left(\lambda_{i t}=\lambda_{i, t+1}=0\right)$ would not face a high shadow cost of external finance, since the firm could reduce dividend payments to finance investment. ${ }^{11}$ Hence, in (15), $\tilde{\omega}_{i t}=0$; and the discount factor, $\beta_{i t}$, assumes the traditional form: $1 /\left(1+(1-\tau) i_{t}-\pi_{t}^{e}\right)$. We will use generalized method of moments (GMM) to test for misspecification of (15). With a set of instrumental variables that are orthogonal to the error term, the orthogonality conditions should not be rejected for (15) under the null hypothesis of no capital-market frictions (that is, where both $\omega_{i t}=0$ and $\lambda_{i t}=0$.) ${ }^{12}$

On the other hand under the alternative model with capitalmarket frictions, $\tilde{\omega}_{i t}$ is not restricted to be zero. Hence, orthogonality conditions associated with (15) under the assumptions of the 
perfect-capital-markets model should be rejected. Under the financingconstraint alternative, orthogonality conditions should be rejected for non-dividend-paying firms and accepted for high-payout firms.

\section{Issues for Econometric Estimation}

Three issues arise in the estimation of equation (12). First, the model is nonlinear in both the parameters and in the ratio of investment to capital, $\left(I_{i t} / K_{i, t-1}\right)$. In addition, there is a simultaneity problem because of the presence of the expected marginal product of capital in the model. These two considerations require estimation by generalized method of moments, where we use the method presented in Newey and West (1987) to obtain a positive-definite optimal weighting matrix. The exact set of instrumental variables used is discussed below and shown in the tables outlining our estimation results.

Second, we want to allow for the possibility that there are fixed firm-specific and time-specific effects in the equation. We include year dummies to deal with the latter. However, because of the presence of the lagged dependent variable, the common practice of eliminating the individual firm effect by removing the means from the variables in the regression will violate the orthogonality conditions used to identify the model. Instead, we first-difference equation (12) and then use twicelagged instruments, which will still be orthogonal to the moving-average error that the differencing creates. 
Finally, the exact form of the model depends on whether the constraints on outside finance bind or not. We consider both possibilities here. First, as suggested in section 2, we split the sample into two groups: those that are a priori constrained and those that are not, using as a criterion the pre-sample dividend payout ratios of the firms. We then use the full sample and the two sub-samples to estimate the model in (12) with the multiplier, $\tilde{\omega}_{i t}$, constrained to equal zero. To estimate the unconstrained model, we parameterize $\tilde{\omega}_{i t}$ as a function of observables.

Jensen (1986) has emphasized a potential link between internal funds and corporate expenditures (including capital spending), holding constant investment opportunities, not arising from financing constraints but from management's use of internal funds for non-valuemaximizing projects. Specifically, Jensen argues that high levels of "free cash flow" (measured as the difference between cash receipts and the sum of cash disbursements and spending on profitable investment opportunities) raise corporate expenditures independent of underlying expected future profitability. Such a measure is unobservable. Precisely in those cases for which the theory is correct, we should be unable to use reported investment data to construct the measure.

Because there are too few firms in our sample in the industries discussed by Jensen (1986)-including petroleum, tobacco, and food products-we sought to define a broader class of "mature" in- 
dustries. In an empirical study of implications of models of oligopoly supergames for the level and adjustment of markups of price over marginal cost, Domowitz, Hubbard, and Petersen (1987) selected 39 4-digit S.I.C. manufacturing industries as "mature" with high average profitability, as measured by the price cost margin over the period from 1958 to $1981 .^{13}$ These industries include those cited by Jensen and share the common characteristics of: (i) being in the "producer goods" sector; ${ }^{14}$ (ii) being recognized by the Census of Manufacturers at least since 1958; (iii) having a four-firm concentration ratio of greater than 0.50 (in 1972) $;^{15}$ and (iv) not being listed as "miscellaneous" or "not elsewhere classified." Though designed for a different purpose, the Domowitz-Hubbard-Petersen criteria identify mature, homogeneous-goods oligopolies operating in well-defined markets.

\section{Data}

Before reporting our estimation results, we describe the data. Most come from the combined annual, research, and full-coverage 1989 COMPUSTAT industrial files. The firms in the combined annual and research files are all listed on either the NYSE or the AMEX and are generally quite large. By contrast, the full-coverage file contains a number of smaller firms whose stock is less actively traded. Such diversity is important to this study, since we focus on potential cross-sectional differences in investment patterns. 
Our sample selection procedure is as follows. First, we consider only the manufacturing sector. Second, we delete any firm with missing or inconsistent data. Finally, we delete any firm that experienced a merger accounting for more than fifteen percent of its value. The sample thus obtained contains 428 firms: 314 from the combined annual file, 34 from the research file, and 80 from the full-coverage file. The sample period runs from 1976 to $1987 .^{16}$

The details of the construction of the regression variables and the instruments can be found in the data appendix in Whited (1992). We discuss the most significant points below. First, we need to express the marginal product of capital in terms of observable measures. If firms are imperfectly competitive and set prices as a constant markup, $\mu$, over marginal cost, then constant returns to scale implies that

$$
F_{K}=\frac{Y_{i, t+1}-\mu C_{i, t+1}}{K_{i t}}
$$

where $Y_{i, t+1}$ is output at time $t+1$ and $C_{i, t+1}$ is real variable costs at time $t+1$. One benefit of this specification is that it provides us with an estimated markup parameter that can be used to assess the model.

Our list of instrumental variables includes twice-lagged values of each of the variables in the model as well as the variables used to parameterize $\tilde{\omega}_{i t}$. In addition, we use depreciation charges divided by the capital stock, interest expense divided by the capital stock, the ratio of the market value of debt to the market value of debt plus equity, the 
ratio of interest expense to the sum of interest expense and cash flow, and the ratio of tax payments to the sum of tax payments and cash flow.

Summary statistics for the sample are shown in Table 1. The first column in the table reports mean and median values for selected variables for the full sample of 428 firms. The heterogeneity which we have discussed is especially clear in terms of size: Comparing the mean and median values for the capital stock measure reveals that there is considerable variation in the size of our firms. Contrasting the mean and median values of the other variables suggests that there may be additional interesting cross-sectional variation in, the propensity to use debt financing (debt-assets ratio) and in retention behavior (payout ratios).

We next report the summary measures after splitting the sample according to the retention and concentration measures introduced earlier. The second column gives statistics for 71 firms we categorize as "high dividend payout" firms. These firms were selected according to their average payout ratio, defined as the ratio of dividends to operating income, in the two years prior to the start of the sample. ${ }^{17} \mathrm{By}$ using pre-sample information for the sorting, we avoid problems arising if firms make their dividend and investment decisions on the basis of common factors that are unobservable to the econometrician. The third column in the table shows statistics for the remaining 357 firms, 
subsequently referred to as either "not high" or "low" dividend paying firms.

Along most dimensions the two sets of firms appear to be similar. There are, however, two striking differences between them. First, and not surprisingly, over the entire sample, the high-dividend-payout firms tend to pay out roughly twice as much of their operating income as dividends to their shareholders. Second, these firms also seem to be noticeably larger than the low-dividend-payout firms. The size differences between the high- and low-payout firms has been widely noted. However, size differences do not seem to account for the reduced form evidence on credit market imperfections mentioned in the introduction (for instance, see Fazzari, Hubbard, and Petersen, 1988; and Gilchrist, 1991). In the last two rows of Table 2, we show that our subsequent Euler equation tests are also not due to pure size differences. ${ }^{18}$ Thus, although there are substantial differences in the typical size of the firms in these two groups, we do not believe that size differences, per se are responsible for the findings in the next section.

In the next column of Table 1 we report summary statistics for firms in the industries that Domowitz, Hubbard, and Petersen (1987), DHP hereafter, classified as mature, concentrated, high-markup industries. We will refer to the 45 firms in our sample in these industries as "mature" firms. Statistics for the remaining 383 "not-mature" firms are shown in the last column of the table. While the concentrated in- 
dustries were selected by DHP for a different purpose, we believe that the firms in these industries conform to a description of firms for which free-cash-flow problems are likely to be severe. Unfortunately, since free cash flow is not observable, verifying this assertion is difficult.

Nevertheless, there is some indirect evidence shown in Table 1 that can be used to assess whether the mature firms fit Jensen's description of firms with high free cash flow. First, the mature firms are typically much larger than the non-mature firms. The free-cashflow approach emphasizes managerial incentives which reward growth (even if it is not in shareholders interests) as one of the key factors underlying his theory. Since mature industries tend to be relatively capital intensive, comparisons of capital stocks probably overstate the size differences. For instance, in terms of debt plus equity, the size gap between the median mature and not-mature firm is closer to a factor of three rather than the factor of four implied by the capital comparison. ${ }^{19}$ Either way, the mature firms are noticeably larger than the not-mature firms, a plausible pattern according to the free-cash-flow story.

Perhaps more important, the mature firms do not seem to have high payout ratios. Despite the large size differences, the median payout rates are nearly identical for the mature and non-mature firms. Given the general tendency for larger firms to pay out more in dividends, this finding is particularly surprising. The reluctance to pay out dividends is one of the principal features of the firms with free cash flow. 
Furthermore, the similarity in payout ratios suggest that the outcome of any tests comparing the mature and not-mature firms could not be inferred merely from knowing the results of analogous tests done using samples selected on the basis of retention behavior. For instance, only 10 of the $\mathbf{4 5}$ mature firms fit our description of high-payout firms. Thus there appears to be useful additional information that can be obtained from analyzing this subsample.

\section{Euler Equation Estimates}

The analysis we present is sequential. Our first step is to estimate equation (12), the baseline neoclassical investment model which assumes perfect capital markets. Under the assumption of no capitalmarket frictions, there are two structural parameters which can be recovered: $\alpha$, the quadratic adjustment parameter and $\mu$, the markup parameter. The point estimates for these parameters, along with standard errors and the J-statistic computed to test the model's overidentifying restrictions are shown in Table 2. The estimates based on the full sample (of 428 firms) are given in the first row. For this sample of firms, the overidentifying restrictions are decisively rejected; the residuals from the equation are strongly correlated with at least some of our instruments. The instruments are listed at the bottom of the table.

Having demonstrated that the standard model is rejected for

the full sample, we next investigate whether this rejection is related to 
retention behavior. The next two rows present the results when the model is reestimated separately for the high- and low-dividend-payout firms. The model performs quite well for the high-payout firms but less satisfactorily for the low-payout firms. In particular, the overidentifying restrictions are strongly rejected for the low-payout firms and not rejected for the high-payout firms. In both cases the estimated markup of prices over costs is plausibly estimated to be between 20 and 40 percent. In addition, for the high payout firms the adjustment cost estimates are more plausible than the estimates typically derived from the $q$-theory approach. ${ }^{20}$ Thus, for the high-dividend-payout firms the standard model seems relatively successful.

A key issue in interpreting the results is whether the rejection for the low-payout firms is indeed due to capital-market frictions. We investigate this question with several different tests. First, we consider the possibility suggested by the free-cash-flow approach. Investment and cash flow may be correlated because of managers opportunistic use of free cash flow. To study this suggestion we further separated the low-payout firms to isolate the mature firms. As we argued earlier, these firms are a priori more susceptible to the agency problems. Therefore, if the problem with the low-payout firms is an excessive amount of free cash flow, then rejection of the model should be most pronounced for this subsample.

The last row in Table 2 shows the estimates for the mature, 
low-payout subsample. The model does reasonably well. Both the estimated markup parameter and the adjustment cost parameter are plausible and in line with the estimates for the other sample splits. Most importantly, the overidentifying restrictions cannot be rejected. Hence, the rejection of the standard model is not traceable to the "mature, low-payout" firms. ${ }^{21}$ We do not view this evidence as particularly damaging to the general assertion that agency-cost considerations might be important. Rather, the free cash flow story does not appear to explain the effect of internal funds, holding constant investment opportunities on investment in plant and equipment. In the remainder of this section, we attempt to rehabilitate the frictionless-capital-markets model to explain the investment by the low-dividend-payout sample of firms. ${ }^{22}$

As next step, we allow the value of $\omega_{i t}$, the multiplier associated with the constraint on outside financing, to vary with internal funds. Our simplest specification allows the extent to which the constraint on debt accumulation binds depends on the firms cash position, i.e.,

$$
\tilde{\omega}_{i t}=\gamma_{0}+\gamma_{1} \frac{C F_{i t}}{K_{i, t-1}}
$$

where $C F_{\text {it }}$ represents the firm's cash flow (earnings plus depreciation charges). As mentioned earlier, this type of constraint has been used in several studies, including Hubbard and Kashyap (1992), Whited (1992), and Himmelberg (1990). Given this parameterization for $\tilde{\omega}_{i t}, \gamma_{1}$ mea- 
sures the change in the firm's effective discount factor which occurs as a result of an increase in internal funds holding constant investment opportunities.

This specification also raises several issues. One would expect that $\gamma_{1}<0$; increases in internal funds, ceteris paribus, relax the constraint on external finance. This same logic has been used to justify the reduced-form test that include measures of internal funds in regressions that also include Tobin's $q$. In that context, one potential objection with using observations of firm cash flow as a measure of internal funds is that shifts in cash flow may contain information about expected future investment opportunities. In our setup the analogous objection would be that the marginal product of capital as parameterized in (16) is mismeasured, so that cash flow again carries information regarding the future profitability of capital. Depending on the serial correlation of the measurement error, it is possible that even lagged values of cash flow would fail to be valid instruments because of the potential correlation with the unobservable component of the marginal product of capital.

To address these concerns, we use firms' corporate tax payments as an instrumental variable. By its statutory description, the corporate income tax is proportional (for firms as large as those in our sample). Nevertheless, there are many reasons to believe that average tax payments are poorly described as the product of the statutory cor- 
porate income tax rate and profits. Sources of this discrepancy include the presence of firms with tax losses (owing to the imperfect loss offsets in the tax code), the use of investment tax credits, and changes in capital recovery provisions in the tax code (see Auerbach and Poterba, 1987; and Altshuler and Auerbach, 1990). Hence, tax payments are only imperfectly correlated with true profits, and their use as an instrument minimizes the importance of this measurement problem. ${ }^{23}$

The results from estimating this augmented model are shown in the first column of Table 3 . The size of the rejection of the model's overidentifying restrictions declines slightly, but nevertheless, the restrictions are still firmly rejected. In addition, the implied impact on the discount rate is quite modest. For instance, a decrease in cash flow relative to capital of 25 percent (e.g., from 0.4 to 0.3 ) would lower the discount factor by just over $0.009(0.086 \times 0.1)$. Given that the average discount factor over the sample period is 0.99 , this difference is quite small.

One reason that this extension of the model may be incomplete is that it implicitly assumes that the constraint is equally binding at all times, so that a given increase in cash flow has the same impact in all periods. To investigate the consequences of this symmetry restriction, we further parameterize $\tilde{\omega}_{i t}$ so that constraint on external finance depends not only on the firm's own cash position but also on a proxy for the overall tightness of borrowing conditions. We use the first differ- 
ence of the spread between the interest rate on six-month commercial paper and the interest rate on six-month Treasury bills as our proxy. ${ }^{24}$ Thus, we now consider the following parameterization for $\tilde{\omega}_{i t}$ :

$$
\tilde{\omega}_{i t}=\gamma_{0}+\gamma_{1} \frac{C F_{i t}}{K_{i t-1}}+\gamma_{2} \Delta s_{t} \frac{C F_{i t}}{K_{i t-1}}
$$

The estimated coefficients from the model incorporating (18) are presented in the second column of Table 3 . Relaxing the symmetry restriction improves the model in a two dimensions. First, the overidentifying restrictions are no longer rejected. Second, the implied size of the changes in the discount factor are more significant. For instance, in the example of a 25 percent drop in cash flow considered above, a concurrent increase in the first difference of the spread of ten basis points would imply a decrease in $\beta$ of 0.037 . Hence, by allowing common movements in credit-market conditions to affect the severity of firm-specific financing constraints we find more variation in firms' implied discount rates, and that the model's restrictions are no longer rejected..$^{25}$

\section{Concluding Remarks}

An emerging literature has suggested that the failure of neoclassical investment models to explain firm-level investment behavior is due to the assumption of frictionless capital markets. While recent empirical studies have concluded that internal funds are likely to be an 
important determinant of investment for many firms in the presence in information imperfections in capital markets, problems of interpretation exist. First, models of investment demand based on Tobin's $q$ or models which use stock market valuation as a proxy for the expected future profitability of invested capital require additional strong assumptions about the efficiency of capital markets. Second, a link between investment and internal funds, holding constant investment opportunities, could also reflect wasteful investment spending by nonvalue-maximizing corporate managers.

This paper addresses these concerns in three parts. First, we formulate tests of the null hypothesis of frictionless capital markets using the Euler equation for intertemporal capital accumulation. We are unable to reject the standard neoclassical model for firms with significant dividend payouts. This model is easily rejected, however, for firms in a low-dividend-payout subsample. Second, to test whether this rejection is traceable to a correlation between internal funds and investment spending and free cash flow considerations, we examine sample splits based on firm "maturity." The model is not rejected for mature firms with low dividend payouts. Finally we specify an alternative model in which firms' cost of funds depends upon firm-specific cash flow and a measure of tightness in aggregate credit conditions. Both measures affect investment for the sample of firms for which the neoclassical model is rejected, and the alternative model is not rejected when both 
additional variables are included.

We believe that our evidence for firm-level investment indicates the significance of capital-market imperfections in affecting investment decisions. At least two directions for future research appear promising. The first is to trace the evolution of firms' terms of trade in capital markets in a model in which firms switch among financing regimes (see, for example, the research agenda outlined in Pakes, 1991). The second is to examine case studies of firms in particular industries for which capital-market frictions appear most relevant (see, for example, Reiss, 1990). 


\section{Literature Cited}

Abel, Andrew. B., and Olivier J. Blanchard. "The Present Value of Profits and Cyclical Movements in Investment." Econometrica 54 (March 1986): 249-273.

Altshuler, Rosanne, and Alan J. Auerbach. "The Significance of Tax Loss Asymmetries: An Empirical Investigation." Quarterly Journal of Economics 105 (February 1990): 61-86.

Auerbach, Alan J. "Wealth Maximization and the Cost of Capital." Quarterly Journal of Economics 93 (August 1979): 433-445.

Auerbach, Alan J., and James M. Poterba. "Why Have Corporate Tax Revenues Declines?" In Tax Policy and The Economy, edited by Lawrence H. Summers, pp. 1-28 Cambridge, Massachusetts: M.I.T. Press, 1987.

Bernanke, Ben S., and John Y. Campbell. "Is There a Corporate Debt Crisis?" Brookings Papers on Economic Activity 1 (1988): 83-125.

Bernanke, Ben S., and Mark Gertler. "Financial Fragility and Economic Performance." Quarterly Journal of Economics 105 (February 1990): 87-114.

Bradford, David F. "The Incidence and Allocation Effects of a Tax on Corporate Distributions." Journal of Public Economics 15 (February 1981): 1-22.

Bond, Stephen, and Costas Meghir. "Dynamic Investment Models and the Firm's Financial Policy." Mimeograph, Oxford University, 1990.

Brainard, William C., John B. Shoven, and Laurence Weiss, "The Financial Valuation of the Return to Capital." Brookings Papers on Economic Activity 2 (1980): 453-512.

Calomiris, Charles W., and R. Glenn Hubbard. "Firm Heterogeneity, Internal Finance, and Credit Rationing." Economic Journal 100 (March 1990): 90-104.

Calomiris, Charles W., and R. Glenn Hubbard. "Tax Policy, Internal Finance, and Investment: Evidence from the Undistributed Profits Tax of 1936-1937." Mimeograph, Columbia University, August 1991. 
Domowitz, Ian, R. Glenn Hubbard, and Bruce C. Petersen. "Oligopoly Supergames: Some Empirical Evidence on Prices and Margins." Journal of Industrial Economics 36 (September 1987): 9-28.

Fazzari, Steven, R. Glenn Hubbard, and Bruce Petersen. "Finance Constraints and Corporate Investment." Brookings Papers on Economic Activity 1 (1988): 141-195.

Feldstein, Martin, and Joosung Jun. "The Effects of Tax Rules on Nonresidential Fixed Investment: Some Preliminary Evidence from the 1980's." In The Effects of Taxation on Capital Accumulation, edited by Martin Feldstein, pp. 101-156. Chicago: University of Chicago Press, 1987.

Friedman, Benjamin J., and Kenneth N. Kuttner. "Money, Income, and Prices and Interest Rates." American Economic Review 82 (June 1992): 472-492.

Gertler, Mark. "Financial Structure and Aggregate Economic Activity." Journal of Money, Credit, and Banking 20 (August 1988, Part II): 559-588.

Gertler, Mark, and R. Glenn Hubbard. "Financial Factors in Business Fluctuations." In Financial Market Volatility, pp. 33-72. Kansas City, Missouri: Federal Reserve Bank of Kansas City, 1988.

Gertler, Mark, R. Glenn Hubbard, and Anil K. Kashyap. "Interest Rate Spreads, Credit Constraints and Investment Fluctuations: An Empirical Investigation." In Financial Markets and Financial Crises, edited by R. Glenn Hubbard, pp. 11-32. Chicago: University of Chicago Press, 1991.

Gilchrist, Simon. "An Empirical Analysis of Corporate Investment and Financing Hierarchies Using Firm Level Panel Data." Mimeograph, Board of Governors of the Federal Reserve System, November 1991 .

Gilchrist, Simon, and Charles P. Himmelberg. "Evidence on the Role of Cash Flow for Investment." Mimeograph, New York University, December 1992.

Greenwald, Bruce, Joseph E. Stiglitz, and Andrew Weiss. "Information Imperfections in the Capital Market and Macroeconomic Fluctuations." American Economic Review 74 (May 1984): 391414.

Hayashi, Fumio. "Tobin's Marginal $q$ and Average $q$ : A Neoclassical Interpretation." Econometrica 50 (January 1982): 213-224. 
Himmelberg, Charles P. "A Dynamic Analysis of Dividend and Investment Behavior Under Borrowing Constraints." Mimeograph, New York University, 1991.

Hoshi, Takeo, Anil K. Kashyap, and David Scharfstein. "Corporate Structure, Liquidity, and Investment: Evidence from Japanese Panel Data." Quarterly Journal of Economics 106 (February 1991): 33-60.

Hubbard, R. Glenn. "Introduction," In Asymmetric Information, Corporate Finance, and Investment, edited by R. Glenn Hubbard, pp. 1-14. Chicago: University of Chicago Press, 1990.

Hubbard, R. Glenn, and Anil K. Kashyap. "Internal Net Worth and the Investment Process: An Application of U.S. Agriculture." Journal of Political Economy 100 (June 1992): 506-534.

Jaffee, Dwight $M$. and Thomas Russell, "Imperfect Information, Uncertainty, and Credit Rationing." Quarterly Journal of Economics 90 (November 1976): 651-666.

Jensen, Michael C. "Agency Costs of Free Cash Flow, Corporate Finance and Takeovers." American Economic Review 76 (May 1986): 323-329.

Kashyap, Anil, Jeremy Stein, and David Wilcox. "Monetary Policy and Credit Conditions: Evidence From the Composition of External Finance." American Economic Review 83 (March 1993): 78-98.

King, Mervyn A. Public Policy and the Corporation. London: Chapman and Hall, 1977.

Leland, Hayne, and David Pyle. "Informational Asymmetries, Financial Structure, and Financial Intermediation." Journal of Finance 32 (May 1977): 371-387.

Meyer, John R., and Edwin Kuh. The Investment Decision. Cambridge, Mass.: Harvard University Press, 1957.

Myers, Stewart C., and Nicholas S. Majluf. "Corporate Financing Decisions When Firms Have Investment Information that Investors Do Not." Journal of Financial Economics 13 (June 1984): 187220.

Newey, Whitney K., and Kenneth D. West. "A Simple, Positive SemiDefinite, Heteroscedasticity and Autocorrelation Consistent Covariance Matrix." Econometrica 55 (May 1987): 703-708. 
Pakes, Ariel. "Dynamic Structural Models: Problems and Prospects." Mimeograph, Yale University, 1991.

Poterba, James M., and Lawrence H. Summers. "The Economic Effects of Dividend Taxation." In Recent Advances in Corporate Finance. edited by Edward I. Altman and Marti G. Subrahmanyam, pp. 227-284. Homewood, Illinois: Richard D. Irwin, 1985.

Reiss, Peter C. "Economic and Financial Determinants of Oil and Gas Exploration Activity." In Asymmetric Information, Corporate Finance, and Investment, edited by R. Glenn Hubbard, pp. 181206. Chicago: University of Chicago Press, 1990.

Stiglitz, Joseph E., and Andrew Weiss. "Credit Rationing in Markets with Imperfect Information." American Economic Review 71 (June 1981): 393-410.

Stock, James H., and Mark W. Watson. "New Indexes of Coincident and Leading Economic Indicators." In NBER Macroeconomics Annual, edited by Olivier Jean Blanchard and Stanley Fischer, pp. 351-393. Cambridge, Massachusetts: MIT Press, 1989.

Summers, Lawrence H. "Taxation and Corporate Investment: A QTheory Approach." Brookings Papers on Economic Activity 1 (1981): $67-127$.

Weiss, Leonard W., and George Pascoe. "Adjusted Concentration Ratios in Manufacturing." Mimeograph, University of Wisconsin, 1981.

Whited, Toni M. "Debt, Liquidity Constraints, and Corporate Investment: Evidence from Panel Data." Journal of Finance 47 (September 1992): 1425-1460. 


\section{Endnotes}

1. See for example Fazzari, Hubbard, and Petersen (1988); Bond and Meghir (1990); Hoshi, Kashyap, and Scharfstein (1991); Whited (1992); Gilchrist (1991); Himmelberg (1991); and Reiss (1990). See Meyer and Kuh (1957) for an early study along these lines. More recently, Gilchrist and Himmelberg (1992) extend the approach suggested originally by Abel and Blanchard (1986) to construct proxies for marginal $q$ in investment equations. They then test whether cash flow is an independent "fundamental" variable explaining investment. They find both that cash flow is an independent fundamental and that excess sensitivity of investment to cash flow is primarily a characteristic of firms with low dividend payouts.

2. See for example Jaffee and Russell (1976); Leland and Pyle (1977); Stiglitz and Weiss (1981); Greenwald, Stiglitz and Weiss (1984); Myers and Majluf (1984); Bernanke and Gertler (1990); Calomiris and Hubbard (1990); and the review of approaches in Gertler (1988).

3. See the studies enumerated in footnote 1 , and the overview in Hubbard (1990).

4. See Fazzari, Hubbard, and Petersen (1988); Gilchrist (1991); Himmelberg (1991), Whited (1992); and Calomiris and Hubbard (1991).

5. We build on the approach developed in Hubbard and Kashyap (1992) and Whited (1992).

6. See Gertler, Hubbard, and Kashyap (1991) and Kashyap, Stein, and Wilcox (1993) for a discussion of these issues.

7. See Gertler and Hubbard (1988) for a formal discussion of this point.

8. This derivation follows Poterba and Summers (1985) and others.

9. Other specifications that satisfy the Hayashi (1982) conditions yield similar Euler equations. For instance, allowing $\psi\left(I_{i t}, K_{i, t-1}\right)$ to be $\left[\alpha_{0}\left(I_{i t} / K_{i, t-1}-v\right)+\left(\alpha_{1} / 2\right)\left(I_{i z} / K_{i, t-1}-v\right)^{2}\right] K_{i, t-1}$ as in Hubbard and Kashyap (1992), then the estimating equations analyzed below are identical except for the constant terms. 
10. This approach implicitly assumes that firms facing imperfections in debt markets face imperfections in new equity finance as well, so that the alternative hypothesis is that external finance from either source is differentially costly relative to internal finance. For example, one could follow the approach taken by Fazzari, Hubbard, and Petersen (1988), who incorporate a "lemons' premium" in the cost of new equity issues.

11. That is, we adopt the "tax capitalization" model of firms' dividend decisions, as in King (1977), Auerbach (1979), and Bradford (1981). In this approach firms would not pay dividends and issue new shares simultaneously, because of adverse tax consequences. Dividend-paying firms are those with cash flows from existing projects exceeding their new investment opportunities. This assumption is really made for simplicity of exposition; firms' dividends may be valued by investors on the basis of agency-cost or other considerations (see Poterba and Summers, 1985, and others). All that is needed for our purposes is to restrict a sample of firms whose significant payout is unlikely to fall below zero.

12. The GMM technique minimizes a quadratic objective function which uses an optimal weighting matrix based on initial parameter estimates. The model will be overidentified as long as the number of instrumental variables used exceeds the number of parameters to be estimated. The test is formulated as follows. Under the null hypothesis of orthogonality of the instruments and the error terms, the product of the minimized value of the objective function and the number of observations is distributed as a $\chi^{2}$ statistic with $n$ degrees of freedom, where $n$ is the difference between the numbers of instruments and parameters. The overidentifying restrictions are rejected if the $\chi^{2}$ value is too high.

13. The industries are described in Domowitz, Hubbard, and Petersen (1987).

14. The producer goods classification is based on the percentage of shipments of output for final demand in four categories: consumption investment, materials, and government. If fifty percent or more of an industry's output went to investment plus materials, it was classified as a producer-goods industry.

15. Domowitz, Hubbard, and Petersen used the four-firm concentration ratios constructed by Weiss and Pascoe (1981), which adjust for inappropriate product groupings and geographic fragmentation.

16. The sample stops in 1987 because of the discontinuity in the accounting data that accompanied COMPUSTAT's shift to reporting consolidated financial reports. 
17. The results reported here are based on a cutoff of 0.17 , and varying this cutoff had little effect.

18. Whited (1992) and Gilchrist (1991) also confirm that size differences do not account for the success or failure of Euler-equation tests for capital market imperfections.

19. Similarly, the ratio of cash flow to assets (debt plus equity) suggests that the mature firms have slightly higher cash flows than the not-mature firms.

20. Given the point estimate for $\alpha$, the marginal cost of adjusting investment, $\psi_{I}$, for the average high payout firm is about 21 cents per dollar. This calculation assumes that $\left(I_{i t} / K_{i, t-1}-v\right)$ is equal to the sample average of 0.1 .

21. To ensure that the differences in statistical significance across subsamples are not merely an artifact of differences in sample size, we conducted the following Monte Carlo experiments. First, we drew with replacement 1000 random samples of size 71 from the not-high-dividend subsample and rejected the model at the nominal 10 percent level 84.3 percent of the time. Second, when we conducted a similar experiment with 1000 random samples of size 35 from the not-mature, not-high-dividend subsample, we rejected the model 74.8 percent of the time. We are grateful to a referee for suggesting this experiment.

22. In what follows, the results are virtually unaffected by whether we include or exclude the $\mathbf{3 5}$ mature firms from the analysis.

23. It is possible, of course, that a rejection of any of our models may be due to the presence of measurement error as well as to misspecification in the presence of financial constraints. Since it is unlikely that measurement error varies systematically across our different samples, we view our pattern of rejections as suggesting capital market imperfections.

24. See Gertler, Hubbard, and Kashyap (1991) and Kashyap, Stein, and Wilcox (1993) for a further discussion of the information content of the spread. Friedman and Kuttner (1992) and Stock and Watson (1989) have noted that this interest-rate differential has had greater predictive power for output (over most of the postwar period) than money, interest rates, or other financial variables.

25. We view this result as only suggestive. One could, for example, use year dummies instead of $s_{t}$. In this case, however, the source of the aggregate effect is unidentified. 


\section{Table 1}

Summary Statistics for Selected Variables

for 428 U.S. Manufacturing Firms, 1976-1987

\begin{tabular}{|c|c|c|c|c|c|}
\hline & \multicolumn{5}{|c|}{ Group of Firms } \\
\hline & $\begin{array}{c}\text { Full } \\
\text { Sample } \\
428 \text { Firms }\end{array}$ & $\begin{array}{c}\text { High } \\
\text { Dividend } \\
71 \text { Firms }\end{array}$ & $\begin{array}{l}\text { Not High } \\
\text { Dividend } \\
357 \text { Firms }\end{array}$ & $\begin{array}{l}\text { Mature } \\
45 \text { Firms }\end{array}$ & $\begin{array}{c}\text { Not } \\
\text { Mature } \\
\text { 383 Firms }\end{array}$ \\
\hline \multicolumn{6}{|l|}{$I_{i t} / K_{i, t-1}$} \\
\hline Mean & .226 & .199 & .231 & .208 & .228 \\
\hline Median & .204 & .100 & .211 & .186 & .205 \\
\hline \multicolumn{6}{|l|}{ Capital Stock } \\
\hline Mean & 1026.5 & 1636.2 & 905.2 & 1056.2 & 1023.8 \\
\hline Median & 88.2 & 275.3 & 72.5 & 336.3 & 78.7 \\
\hline \multicolumn{6}{|l|}{$C F_{i t} / K_{i, t-1}$} \\
\hline Mean & .389 & .408 & .386 & .309 & .396 \\
\hline Median & .343 & .335 & .345 & .281 & .348 \\
\hline \multicolumn{6}{|l|}{$Y_{i t} / K_{i, t-1}$} \\
\hline Mean & 4.78 & 4.18 & 4.91 & 3.66 & 4.89 \\
\hline Median & 4.12 & 3.26 & 4.23 & 2.76 & 4.20 \\
\hline \multicolumn{6}{|l|}{ Debt Assets Ratio } \\
\hline Mean & .248 & .208 & .256 & .282 & .245 \\
\hline Median & .209 & .179 & .218 & .235 & .207 \\
\hline \multicolumn{6}{|l|}{ Interest Coverage } \\
\hline Mean & .141 & .121 & .145 & .135 & .142 \\
\hline Median & .137 & .118 & .140 & .142 & .137 \\
\hline \multicolumn{6}{|l|}{ Payout Ratio } \\
\hline Mean & .142 & .254 & .120 & .258 & .132 \\
\hline Median & .118 & .200 & .107 & .115 & .118 \\
\hline
\end{tabular}

Definitions:

$I_{i t} / K_{i, t-1}=$ (this year's investment) $/($ the replacement value of last year's capital stock)

Capital Stock $=$ the replacement value of plant, property, and equipment (millions of 1982 dollars)

$C F_{i t} / K_{i, t-1}=$ (operating income plus depreciation charges)/(the replacement value of last year's capital stock)

$Y_{i t} / K_{i, t-1}=$ (this year's output) $/($ the replacement value of last year's capital stock)

Debt Assets Ratio = (the market value of debt)/(the market value of debt plus equity)

Interest Coverage $=$ (interest payments) $/$ (interest payments plus cash flow plus 4 (to ensure a positive number))

Payout Ratio $=$ (dividends) $/$ (operating income) 
Table 2

Perfect-Markets, Neoclassical Investment Model, 1976-1987 ${ }^{a}$

\begin{tabular}{|c|c|c|c|}
\hline & $\begin{array}{c}\text { Adjustment } \\
\text { Cost } \\
\text { Parameter } \\
\alpha \\
\end{array}$ & Markup & $\begin{array}{c}\text { Test of } \\
\text { Overidentifying } \\
\text { Restrictions } \\
\chi_{9}^{2} \\
\end{array}$ \\
\hline $\begin{array}{l}\text { Full Sample } \\
428 \text { firms }\end{array}$ & $\begin{array}{l}1.104^{* *} \\
(0.312)\end{array}$ & $\begin{array}{l}1.360^{* *} \\
(0.065)\end{array}$ & $\begin{array}{c}46.12 \\
\left(5.7 \times 10^{-7}\right)\end{array}$ \\
\hline $\begin{array}{l}\text { High Dividend } \\
71 \text { firms }\end{array}$ & $\begin{array}{l}2.251^{* *} \\
(0.830)\end{array}$ & $\begin{array}{l}1.286^{* *} \\
(0.144)\end{array}$ & $\begin{array}{c}7.95 \\
(0.539)\end{array}$ \\
\hline $\begin{array}{l}\text { Not-High Dividend } \\
357 \text { firms }\end{array}$ & $\begin{array}{l}0.761^{* *} \\
(0.276)\end{array}$ & $\begin{array}{l}1.302^{* *} \\
(0.058)\end{array}$ & $\begin{array}{c}55.57 \\
\left(9.5 \times 10^{-9}\right)\end{array}$ \\
\hline $\begin{array}{l}\text { Mature and } \\
\text { Not-High Dividend } \\
35 \text { firms }\end{array}$ & $\begin{array}{c}0.731 \\
(0.685)\end{array}$ & $\begin{array}{l}1.178^{* *} \\
(0.094)\end{array}$ & $\begin{array}{c}13.61 \\
(0.137)\end{array}$ \\
\hline $\begin{array}{l}\text { Large } \\
107 \text { firms }\end{array}$ & $\begin{array}{l}1.666^{*} \\
(0.982)\end{array}$ & $\begin{array}{l}1.312^{* *} \\
(0.078)\end{array}$ & $\begin{array}{c}32.17 \\
\left(1.9 \times 10^{-4}\right)\end{array}$ \\
\hline $\begin{array}{l}\text { Small } \\
321 \text { firms }\end{array}$ & $\begin{array}{l}0.775^{* *} \\
(0.278)\end{array}$ & $\begin{array}{l}1.346^{* *} \\
(0.069)\end{array}$ & $\begin{array}{c}41.24 \\
\left(4.5 \times 10^{-6}\right)\end{array}$ \\
\hline
\end{tabular}

aStandard errors are shown in parentheses. The standard errors are corrected for the moving average errors induced by differencing using the Newey-West (1987) procedure. Coefficients significant at the $5 \%$ level are indicated with two asterisks; one asterisk indicates signigicance at the $10 \%$ level. Significance levels for tests of overidentifying restrictions are shown in parentheses beneath the test statistic.

The instrument set used in estimation includes $I / K,(I / K)^{2}$, Output/K, (Price of Capital)/(Price of Output), Taxes/K, Depreciation Charges/K, Interest Expense/K, Debt/Assets, Interest Coverage, Taxes/(Taxes + Cash flow), (Cost of goods sold + General Selling and Administrative Expenses)/K. All variables are lagged two periods and the capital stocks used in the normalizations are always measured as of the beginning of the period. 


\section{Table 3}

Neoclassical Investment Model Augmented for both Firm-Specific and Time-Varying Capital Market Imperfections (357 Firms with Low Payout Ratios, 1976-1987) ${ }^{a}$

\begin{tabular}{lcc}
\hline \hline Adjustment Cost & 0.967 & $1.277^{* *}$ \\
Parameter $-\alpha$ & $(0.683)$ & $(0.501)$ \\
& & \\
Mark-up - $\mu$ & $1.358^{* * *}$ & $1.409^{* *}$ \\
& $(0.083)$ & $(0.068)$ \\
Shadow Cost, & & \\
Firm specific $-\gamma_{1}$ & $-0.086^{* * *}$ & -0.138 \\
& $(0.005)$ & $(0.104)$ \\
Shadow Cost, & & $-0.024^{*}$ \\
time varying $-\gamma_{2} \times \Delta s_{t}$ & & $(0.012)$ \\
& & \\
Test of Overidentifying & 15.81 & 7.47 \\
Restrictions $-\chi^{2}$ & $(0.015)$ & $(0.188)$ \\
\hline
\end{tabular}

a Standard errors are shown in parentheses. The standard errors are corrected for the moving average errors induced by differencing using the Newey-West (1987) procedure. Coefficients significant at the $5 \%$ level are indicated with two asterisks; one asterisk indicates signigicance at the $10 \%$ level. Significance levels for tests of overidentifying restrictions are shown in parentheses beneath the test statistic.

The instrument set used in estimation includes $I / K,(I / K)^{2}$, Output/K, (Price of Capital)/(Price of Output), Taxes/K, Depreciation Charges/K, Interest Expense/K, Debt/Assets, Interest Coverage, Taxes/(Taxes + Cash flow), (Cost of goods sold + General Selling and Administrative Expenses)/K. All variables are lagged two periods and the capital stocks used in the normalizations are always measured as of the beginning of the period. There are 7 and 6 overidentifying restriction for the models in columns 2 and 3 , respectively. 